\title{
But Our Natives Are Different! \\ Race, Knowledge and Power in the Academy ${ }^{1}$
}

\section{Jonathan D. Jansen}

Faculty of Education

University of Durban Westville

What methodologies are appropriate for the study of transformation? ${ }^{2}$ A conventional inquiry might begin with an analysis of official documents searching for mission statements, three-year rolling plans, special pronouncements of university management, strategic plans, vision statements and the like. Realising that such visionary plans are at best political symbols signalling broad orientations, a more technical inquiry might insist on outputs. Such a strategy would examine demonstrable achievements in a university against pre-specified performance indicators such as may be required under the new system of institutional quality audits flowing from the White Paper on Higher Education. But even an impact assessment of this kind signals little of the depth, quality and sustainability of transformation given the fixation of this approach with numerical indices of performance such as 'number of African students enrolled' without inquiring, for example, about the nature of their curriculum experience within a white university.

I wish to propose that a better way to understand transformation might be through the study of critical incidents. The argument presented is that one understands transformation much better when someone throws the proverbial 'spanner in the works.' An institution provoked through crisis tells us much more about the nature and extent of transformation than any official documents or quantified outputs. For it is in the response of the institution to such critical incidents that important clues are given away about how far that institution has travelled in the direction of what it may call 'transformation.' It took the so-called 'Makgoba affair' at the University of the Witwatersrand to expose the dynamics of race and authority in an institution that had embarked on a fierce public campaign to sell itself as occupying the transformation high road. It took the 'language crisis' at the University of Stellenbosch to unravel 
the inertia around transformation where the medium of instruction (Afrikaans) was clearly demonstrated to be a latter-day race exclusion device in an institution where matters of curriculum and language have remained more or less static for more than eighty years. And it was only through the Mamdani affair at the University of Cape Town (UCT) that transformation could be assessed in an institution which had displayed all the cosmetics of change - a black, woman vice-chancellor, an overused liberal claim to having resisted race-based admission policies under apartheid, an eye-catching caption appearing regularly in national newspapers (as part of post advertisements) about being a 'world-class African university.' Such "critical events" have both "a confirmatory and preservation function in sustaining [institutional] beliefs, interests and commitments, and aiding strategic redefinition" but they are also "unplanned, unanticipated and uncontrolled ... flashpoints that illuminate in some electrifying instant some key aspect of the [institution's] role and which contain, in the same instant, the solution."

What, then, does the Mamdani Affair tell us about transformation at UCT?

Having posed the question this way, it should be clear that I am less concerned with whether Mamdani or his detractors were 'right' or 'wrong'; I am, however, interested in holding up the mirror of the Mamdani experience to reflect back to the institution its own crisis of transfomation in a way that only such a critical incident could allow us to understand the University of Cape Town after apartheid.

At a first glance, the UCT crisis appears confusing. Mahmood Mamdani raises several critical issues about the nature of an undergraduate curriculum on Africa. The respondents, including the vice-chancellor and a host of senior academics, respond with various degrees of indignation, but equal intensity, targeting the same source: Mamdani. The problem is that not only are all of the respondents raising somewhat different issues against Mamdani; all of them appear, remarkably, to have missed the critical questions that Mamdani raises. Johan Muller concludes, mistakenly in my view, that "we are not going to get to the bottom of an argument where the protagonists insist that the debate is about different topics".

On closer examination, I do not believe that the respondents misunderstand Mamdani at all. My contention is that they are unable to provide an intellectually honest response to Mamdani because the issues he raises 
challenges at its very roots a knowledge/power regime at UCT which is intimately connected to the history and politics of a white institution in the shadow of apartheid.

Mamdani's principal thesis is quite simple: the Introductory Africa Course (IAC) represents a colonial conception of Africa which is projected and reinforced through its particular selection of political geography, research methodology, pedagogical expertise, acknowledged authorities and political periodisation. In his words: ${ }^{4}$

1. The IAC represents a colonial view of Africa: that Africa is Equatorial Africa (spatially) and Bantu Africa (socially), lying between the Limpopo and the Sahara; that is, which Africa is taught?

2. The IAC while focussing on equatorial Africa does not have the expertise (or the ability to recognise such expertise) in teaching this section of Africa; that is, who teaches Africa?

3. The IAC draws on a limited set of disciplinary perspectives that do not allow a dynamic social history of Africa, simply a static material history of artefacts and objects; that is, what are more appropriate methodologies for studying Africa?

4. The IAC reinforces a racial reading of Africa by not incorporating "African intelligentsia" in the core readings relying rather on text which represent the American academy's perspective on African Studies; that is, which authorities are invoked in the study of Africa?

5. The IAC presents a racial periodisation of African history (precolonial, colonial, post-colonial), leading to this concluding logic: "disintegration following the departure of the White Man"; that is, how should Africa be taught?

These questions and challenges posed by Mamdani take us to underlying and untouched concerns in higher education transformation; issues of curriculum knowledge and institutional power.

But why is it that the Mamdani affair generated so much intellectual debate and popular publicity? I would like to suggest at least two major reasons. 
First, higher education institutions, especially those with white liberal histories, have become settled in limiting the meaning of transformation to changes in the racial demography of students and, more recently, staff. Seldom has this debate been infused downwards into the substance of pedagogy, curriculum and assessment as a transformation project. This narrow interpretation of transformation in terms of racial accounting is becoming meaningless as universities inescapably begin to reflect in their student composition their regional race distribution and as issues of social class become more salient in determining what kinds of students gain access to what kinds of universities. The point in focus is that the preoccupation with racial demographics rather than curriculum content has left unchallenged the Achilles heel of white institutions: the kind of knowledge (and therefore authority) which is passed on to African students as unquestionable truth and inscrutable value. The mathematician George Ellis, one of Mamdani's critics, makes my point well:

We can be proud of what has been achieved through ... careful and painstakingiy developed programmes. Professor Mamdani proposes we reject all this valuable knowledge and developmental work and instead throw (sic) high-level work at first year students without taking cognisance of their level of academic development and achieverzent. $^{\text {s }}$

It would take another paper to deconstruct George Ellis' persistent "we" in his response and the implicit positioning of Mamdani as the other (them), but I rather wish to discuss the latter point invoked as a defence of the curriculum status quo by Mamdani's critics i.e., academic development $(\mathrm{AD})$ and the needs of disadvantaged students. The arguments of the critics contradict each other, but all conclude that $\mathrm{AD}$ and its skills-emphasis are appropriate and essential for first-year students. For Martin Hall, students with the aptitude to succeed but who are burdened by the heritage of apartheid education in their prior schooling will not have the opportunity of becoming the intelligentsia of the future if they are expected to understand an alien academic discourse without the right support. ${ }^{6}$

For Nadia Hartman, a seasoned AD veteran, it is not primarily about disadvantaged students and English as a Second Language, but how to increase the access of a wider range of students to these academic discourses, maximise opportunities for becoming genuine participants in the discourse analysis and construction and reducing the dropout and failure-rates. ${ }^{3}$ 
For Johann Graaff it is, and perhaps is not, about disadvantage:

I might have argued, with regard to the sophistication and volume of material in first year courses, that I have been teaching South African ESL students for 25 years, and that one thing I have learnt is that a very good way to demoralise and fail them is to subject them to material which is over their heads.

All of this in response to Mamdani's principal criticism of the AD orientation:

Why is this disadvantaged student body being fod a disadvantaged curriculum? Is UCT in the process of creating its own version of Bantu education?"

Mamdani clearly views the content of the curriculum as sub-standard and misleading; his critics elevate pedagogy and appropriateness for disadvantaged students (the essence of an $\mathrm{AD}$ orientation) to a primary intervention in the lives of the disadvantaged.

Again, I am not interested in assuming a possible adjudication role as to who is 'right' in this debate. What I do want to comment on briefly is the way in which the disadvantaged student has boen framed at UCT (and indeed elsewhere) and how this framing has constituted the undergraduate curriculum.

There is an ominous ring to the incensed responses of the critics that they have figured-out the 'disadvantaged student', shorthand for avoiding the more appropriate label, black student. These white critics cite various years of experience to stake their claim of having understood disadvantaged students and their noeds. My first problem is that to understand disadvantaged students, you need to understand something about disadvantage, and that is not simply about disseminating a de-racialised pedagogy; it is, crucially, about who teaches Africa.

My second problem is the content-pedagogy dichotomy that came to characterise the Mamdani debate; in the words of the Deputy Dean, the content was arbitrary; what matters is appropriate pedagogy for disadvantaged students. I wish to argue from personal, documented experience with 320 'disadvantaged students' each year, that high-quality, challenging content can be taught to black students provided its is accompanied by high-quality, challenging pedagogy, and high-quality, challenging assessment; anything less is Bantu Education. Content matters, and it matters a great deal when a European-centred curriculum continues to dominate and define what counts as worthwhile knowlodge and legitimate 
authority in South African texts and teaching; it matters very much in the context of the inherited curriculum, informed by apartheid and colonialism, in which only the more readily observable, offensive racism has been skimmed off the top; ${ }^{10}$ and it matters in an institutional culture where the intellectual leadership (all Deans concerned were white) has its origins, training, qualifications and academic enculturation firmly lodged in an environment foreign and alienating to the so-called 'disadvantaged student.'

My third problem with the evangelical authority of the $\mathrm{AD}$ curricuhum is both its conceptualisation and track record. In terms of conceptualisation, the $\mathrm{AD}$ curriculum in general, as demonstrated by Mamdani's critics, has consistently gained institutional ground by framing the black student within a deficit discourse; it is what they do not have that constitutes the curricular response. Rather than see students as reservoirs of experience and knowledge which can contribute to, even define, the curriculum, these students are either lacking language (that is, English) skills or reasoning abilities or writing competencies, and so on. What this conception does is leave outside of critical inquiry some basic questions, such as: What if the problem was framed as the incapacity of the UCT staff to teach in Xhosa or Afrikaans? Why make the student the object of a deficit gaze, and not the staff? Whose problem is it really? And is it not a point of consideration that given their capacity to survive the hazards of an as yet unequal education, the students who gain access to UCT should already have considerable competencies and potentials to draw on for the institutional curriculum? Which brings me to the track record of $\mathrm{AD}$ programmes throughout South Africa. There are few, if any, institutions which would have the audacity to claim that AD has promoted 'disadvantaged students' as a group despite investments of millions of Rands in such programmes. To be sure, there are spectacular examples of individuals who have excelled within (despite?) AD programmes, but these are isolated cases and ones in which causality is difficult to prove. And so the faith in $\mathrm{AD}$ expressed by the Mamdani critics is suspect, to say the least. Yet the discourse of disadvantage ('Mamdani simply does not understand the native') in this debate became in fact a sheltering canopy under which bruised egos and treasured traditions took defensive refuge.

Second, higher education policy has itself not placed the university curriculum centre-stage in the ongoing struggle for transformation. Rather, two largely alien though related debates (in terms of the history of 
knowledge/power struggles in South African institutions) have occupied the curriculum landscape in higher education: the one powerful and bureaucratic, the other marginal and academic.

The first and more powerful discourse comes in the form of the National Qualifications Framework (NQF) and its offspring policies - such as the Norms and Standards for Teacher Education (earlier known as COTEP, the Committee on Teacher Education Policy). The Framework has imprinted a highly structuralist knowledge regime on the identity of higher education institutions replete with the often impenetrable regulatory languages of credit hours, unit standards, outcomes-based education, performance indicators, equivalencies, qualifications etc. To be sure, the justification of such a formatting knowledge is seductive, bathed in the rhetoric of quality, assurance, account-ability (sic), mobility, the recognition of prior learning, portability, inequality and redress. Yet those of us working in universities at the whipping end of the NQF could readily testify to the increasing bureaucratisation of higher education policy and the coercive instruments for implementation, not the least of which is the linking of state funding to particular kinds of curriculum formatting i.e., the type which is programmebased, unit standardised, outcomes oriented (forget the process), economically relevant (read: 'science and technology') and financially feasible (exclude the Humanities). My concern is not with the NQF per se, but how its epistemological structuralism and economic underpinnings have in fact displaced concern with the politics of knowledge embedded in the inherited curriculum, whose innocence Mamdani uncovered.

One such attendant NQF policy is outcomes based education (OBE) and, specifically, the proposition that qualifications be determined on the basis of demonstrable outcomes and that the meaning of such qualifications be rendered through a process called "integrated assessment." II I have provided elsewhere an extensive critique of OBE in the school setting ${ }^{12}$ but my focus here concerns the implications of 'outcomes' for the university curriculum in the context of the Mamdani debate. The focus on outcomes trivialises content by separating execution from conception; demonstration from comprehension; the observable (what the leamer can do) from the emotional, psychological and spiritual (what the learner feels and appreciates); the culminating behaviour (in the words of William Spady, the American 'father' of OBE) from the cumulative learning process. In short, the national policy focus on 
'outcomes' and the UCT institutional emphasis on 'pedagogy' represents an idcological convergence that leaves the substance of learning (content) untouched in transformation moves around the university curriculum.

A second though largely academic discourse has been that concerned with new developments in global knowledge production; a kind of knowledge, we are told, which is increasingly problem-based, trans-disciplinary (not restricted to academic disciplines or canons), produced in many different 'production sites' (not only universities) and which has social and commercial value. These debates are reflected in the recent monograph Knowledge, Identity and Curriculum Transformation in Afric ${ }^{13}$ and provided the starting focus of the National Commission on Higher Education and its related products, the White Papers on Higher Education and Science and Technology. What this debate did was to circumscribe our attention around the globalisation of knowledge, the competitive and trade value of knowledge as a commercial product, and the significance of non-university settings in knowledge production. The uncritical consumption of this European debate within an African context is not the issue I wish to engage in this paper. My point is that again the politics of curriculum, inherited and ingrained in the institutional fabric of white universities (and also black), was side-stepped in an externalising logic which displaced power and knowledge contestations away from the academy and into the global marketplace.

All this to say that the Mamdani debate came almost too late in the short window period afforded to South Africans to engage what threatens to shortly become sedimented under the bureaucratic weight of the NQF i.e., the knowledge privileged and submerged within universities; the redemptive pedagogies taken-for-granted in the unrelenting logic of the curriculum status quo: 'what is best for disadvantaged students?' The external authoritics (mainly European, to some extent North American) invoked and sanctified to legitimate African experiences; the racialised and racist logics governing the university curriculum; and the bloodless severance of knowledge from experience in the selection (or non-selection) of those deemed qualified to teach Africa.

But what is of equal concern in the Mamdani debate is the underlying 'broeder' symbolism, which came to shape both the criticism and the cast of critics in white universities. The critics, without noticeable exception, are white and English. The tone (sic) of the critics is, with few exceptions, 
sarcastic, dismissive and unyielding. Now Mamdani is no angel, and he has launched his missive with equal ferocity. But he stands alone, as an invited Ugandan scholar in African Studies at UCT, surrounded by this laager of angry white liberal voices. Not surprisingly, a black student who witnessed the public debate on the Mamdani position at a Seminar on the Africa Core of the Foundations Course (22 April 1998), understood the symbolism of the moment, as the first time she saw "a black person kicking arse at UCT."14

Indeed, the list-serve discussion on NUAFRICA involving mainly white liberal universities (Natal and Wits) is vicious and insulting. Says Robert Thornton in a "facetious but practical" parenthetical through this email discussion:

he [Mamdani] should set his speli-checker to use South African English rather than American. It might help warm up the English-speaking classes if not the masses. And even Microsoft recognises this degree of 'South Africen exceptionalism'. 15

Such insults continued. Professor Martin Hall, one of the critics, says the problem is Mamdani's inability to appreciate the team approach; ${ }^{16}$ Professor Ellis, again positioning Mamdani outside the UCT circle, stands aloof: "we deserve a higher level of academic rigour and responsibility than is displayed" by Mamdani's "carelessness" in his assessment of the IAC. ${ }^{17}$ Such distracting, negative references suggest that what Mamdani may have done was to touch a raw nerve in the post-apartheid curriculum debate: the colonial fingerprints of the curriculum makers, their own prejudices and histories, passed-on to unsuspecting black students as tried and tested truth. He questions not only the geography of Africa, but also those who defined it: white, tribal, privileged, powerful. For Mamdani, curriculum is identity, and this crucial point is missed by his detractors but recognised by those who engage his work seriously:

In the context of South Africa the post-apartheid conjuncture throws up numerous possibilities for the diverse groups and interests involved in this transformative phase in its history. It is in this context that the kind of scholarship or knowiedge production, which Mamdani represents, becomes important: a scholarship that challenges our conception of Africa and the world. But how knowledge or knowledges are produced and for whom become key questions in a situation of diverse interest and unstated agendas. It is not only an intellectual question but also a political and cultural one. ${ }^{18}$ 
To conclude, a much more appropriate response by the UCT powerful to Mamdani's analysis might have been strategic, even opportunistic, looking for learning in the crucial issues raised. As Ran Greenstein so eloquently put it:

One may argue with some of his analyses and conciusions, but his larger point stands. He has managed to offer new avenues of investigation, and help in opening up the insular terrain on which South Africans (and South Africanists) have worked in the past three decades. The question we must now ask ourselves is this: when we look at South Africa now ('post-Mamdani'), do we have at our disposal new questions, new tools, more exciting ways of looking at our analytical tasks?

\section{Notes}

1 This paper is being prepared on invitation for the journal Sacial Dymamics, and should not be cited without the express permission of the author, contactable on email: jjansen@pixie.udw.ac.za

2 I am grateful to Gitanjali Maharaj of IDASA for first raising this critical question in discussion.

3 Background Briefing to Commentators, 3 June 1998, p.4

4 I am drawing on Mamdani's "Teaching Africa at the Post-Apartheid University of Cape Town: A Critical View of the 'Introduction to Africa' Core Course in the Social Science and Humanities Faculty's Foundation Semester, 1998," (published in this volume pp.1-32) and "Is African Studies to be Turned into a New Home for Bantu Education at UCT?" (published in this volume pp.6375).

5 Ellis, G. 1998. "Teaching Africa at Post-Apartheid UCT," Mathematics Department, UCT.

6 Hall, M. 1998. "Teaching Africa ..: A Response" (published in this volume pp. $40-62)$.

7 Hartman, N. 1998. "Discussion of Certain Aspects of Mamdani's Paper," (published in this volume pp.33-39).

8 Graaff, J. 1998. "Pandering to Pedagogy or Consurned by Content," (published in this volume: p.78) 


\section{University of Pretoria, J Jansen Collection}

9 Mandani, M. 1998. "Is African Studies to be Turned into a New Home for Bantu Education at UCT?' (published in this volume: 72).

10 One is less likely to encounter the explicit racism found in university curricula of the $1980 \mathrm{~s}$, as documented in several sources including the edited monograph, Knowledge and Power in South Africa: Critical Perspectives Across the Disciplines. Johannesburg: Skotaville Publishers.

II For a fuller discussion on this specific issue sce Jansen, J. 1998. 'Integrated Assessment: Meanings, Motivations, Methods.' Paper presented to the South African Registrars Forum, University of Durban Westville, July 1998.

12 See Jansen, J. 1998. "The Limitations of Outcomes Based Education." Cambridge Journal of Education. Forthcoming.

13 Cloete, N., Muller, J., Makgoba, W. \& Ekong, D. (Eds.). 1997. Knowledge, Identity and Curriculum Transformation in Africa. Cape Town: Maskew Miller Longman.

14 Dikeni, S. 1998. "In the Shadow of 'Entabeni"'. Siyaya!. Issue 2: Winter: pp. 52-55 (An IDASA publication).

is Robert Thornton, 21 May 1998 on nuafrica@listserv.acns.nwu.edu

16 The South African tendency to extricate itself from its commonness with the African experience is something not only raised by Mamdani in his writings on the IAC, but also in his Inaugural Lecture and his book, Citizen and Subject.

17 Cited in Dikeni 1998 (above).

18 Professor A. Temu (1998) in his Vote of Thanks on the occasion of Mamdani's Inaugural Lecture as AC Jordan Professor of African Studies at UCT, "When Does a Settler Become a Native? Reflections of the Colonial Roots of Citizenship in Equatorial and South Africa," May 13, 1998.

19 Ran Greenstein (1998), mailto:nuafrica@listserv.acns.nwu.edu (May). 